\title{
Chemical Composition and In Vitro Antimicrobial Activity of the Essential Oil Obtained from Eugenia pyriformis Cambess. (Myrtaceae)
}

Angela Maria de Souza ${ }^{1 *}$

https://orcid.org/0000-0003-4197-1121

Vinícius Bednarczuk de Oliveira ${ }^{1}$

https://orcid.org/0000-0001-7821-7742

Camila Freitas de Oliveira ${ }^{1}$

https://orcid.org/0000-0002-8549-5182

\section{Fernando Cesar Martins Betim ${ }^{1}$}

https://orcid.org/0000-0002-1668-8626
Samanta Daliana Golin Pacheco ${ }^{1}$
https://orcid.org/0000-0003-1527-4218

Laura Lúcia Cogo ${ }^{2}$

https://orcid.org/0000-0003-0469-8883

Obdulio Gomes Miguel ${ }^{1}$

https://orcid.org/0000-0002-2231-9130

Marilis Dallarmi Miguel ${ }^{1}$

https://orcid.org/0000-0002-1126-9211

${ }^{1}$ Federal University of Paraná, Postgraduate Program in Pharmaceutical Sciences, Department of Pharmacy, Curitiba, Paraná, Brazil; ' $F$ Federal University of Paraná, Unit of the Laboratory of Clinical Analyzes of the Hospital of Clinics, Sector of microbiology, Curitiba, Paraná, Brazil.

Editor-in-Chief: Paulo Vitor Farago

Associate Editor: Paulo Vitor Farago

Received: 2020.10.15; Accepted 2021.02.24.

*Correspondência: angelasouza68@hotmail.com; Tel.: +55-41-988272731 (A.M.S.)

\section{HIGHLIGHTS}

- $\quad \beta$-caryophyllene, bicyclogermacrene, globulol, and $\delta$-cadinene were de major constituents.

- Antimicrobial activity was tested with twelve microorganisms of interest.

- Promissing antibacterial activity of essential oil against several gram-positive bacteria.

- The essential oil showed marked toxicity to A. salina.

Abstract: Our study aimed to evaluate the chemical composition of the essential oil from the leaves of Eugenia pyriformis Cambess., belonging to the Myrtaceae family and native to the Brazilian Atlantic forest. The volatile compounds in the essential oil were extracted by hydrodistillation and analyzed using GC-MS; 36 compounds accounted for $78.80 \%$ of the total oil content. The major compounds were $\beta$-caryophyllene, bicyclogermacrene, globulol, and $\delta$-cadinene. We evaluated their antimicrobial potential of the essential oil and toxicity to Artemia salina. The antimicrobial activity of the essential oil was evaluated against 12 microorganisms using the broth microdilution method. Our results showed moderate inhibition of Staphylococcus aureus and methicillin-resistant S. aureus (MIC, 250 and $125 \mu \mathrm{g} \cdot \mathrm{mL}^{-1}$, respectively) and toxicity to $A$. salina (LC50, $\left.125.64 \mu \mathrm{g} \cdot \mathrm{mL}^{-1}\right)$. Our results establish the biological activity of the essential oil obtained from E. pyriformis.

Keywords: Eugenia pyriformis; chemical composition; essential oil; antimicrobial activity. 


\section{GRAPHICAL ABSTRACT}

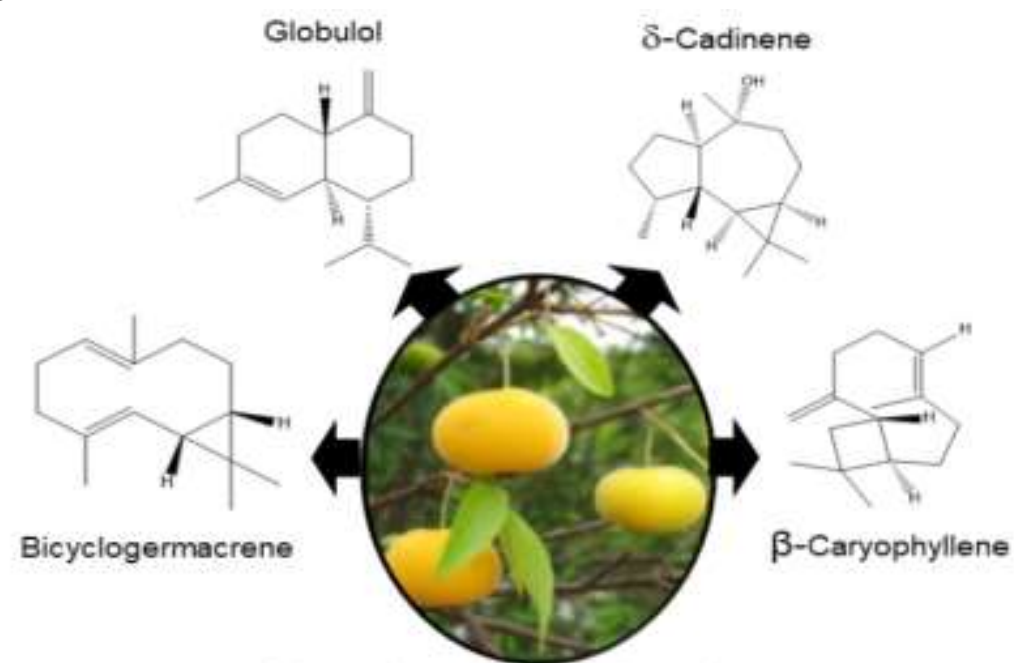

Eugenia pyriformis Cambess.

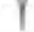

Chemical compostition

Antimicrobial activity

Brine Shrimp Lethality Bioassay

\section{INTRODUCTION}

The genus Eugenia are the fourth largest producers of essential oils among the plants of the Myrtaceae family $[1,2]$. The Myrtaceae family are found in the Americas and Oceania and in the tropical and subtropical regions of the world [3]. Twenty three genera and 1000 species to the Myrtaceae family are found in Brazil [4].

Most plants of the genus Eugenia have been used ethnopharmacologically for the treatment of various diseases such as infectious diseases, intestinal infections, gastrointestinal disorders, for the treatment of wounds, or as repellents or insecticides against domestic and agricultural pests [5,6]. Previous studies have shown positive antibacterial and antifungal effects of the essential oils obtained from plants belonging to this genus. Eugenia axillaris exerts antibacterial and antifungal effects with a minimum inhibitory concentration (MIC) of $625 \mu \mathrm{g} \cdot \mathrm{mL}^{-1}$ against Pseudomonas aeruginosa, Staphylococcus aureus, Escherichia coli and Candida albicans [7]. In addition, the essential oils obtained from E. brasiliensis, E. beaurepaireana, and $E$. umbelliflora were active against strains of $S$. aureus, $P$. aeruginosa, and $E$. coli with MICs ranging from 156.2 to $624.9 \mu \mathrm{g} \cdot \mathrm{mL}^{-1}$ [8]. These effects have been attributed to the presence of active constituents, particularly the cyclic sesquiterpenes and monoterpenes in smaller amounts. Typically, the monoterpene $\alpha$-pinene and the sesquiterpene $\beta$-caryophyllene are present in high amounts in plants of this genus [9].

This study focuses on the E. pyriformis Cambess., which is known as uvaia, uvaieira, uvalha, uvalheira, or uvalha-do-campo; it is a fruit tree native to Brazil and is found in the states of São Paulo, Paraná, Santa Catarina, and Rio Grande do Sul [10]. The essential oil obtained from this tree has not been extensively investigated; some studies have reported the antimicrobial activity of the extracts and fractions obtained from the stem, leaves, fruits, and seeds of this tree against various strains of bacteria and fungi. Souza et al. [4] showed that the ketone extract obtained from the stem and leaves of $E$. pyriformis had a marked antimicrobial effect against Enterococcus faecalis and $S$. aureus $\left(\mathrm{MIC}=62.5-125 \mu \mathrm{g} \cdot \mathrm{mL}^{-1}\right)$ and an antifungal effect against the leveduriformes species of fungi $C$. albicans, $C$. parapsilosis, and $C$. krusei $\left(\mathrm{MIC}=7.81 \mu \mathrm{g} \cdot \mathrm{mL}^{-1}\right)$. Our study aims to evaluate the composition of the essential oil obtained from E. pyriformis Cambess. and investigate its antimicrobial activity and preliminary toxicity and thus provide information about the therapeutic effects of this species. 


\section{MATERIAL AND METHODS}

\section{Plant material}

Aerial parts of E. pyriformis Cambess. were collected from Curitiba, Paraná State $\left(25^{\circ} 26^{\prime} 51.83^{\prime \prime} \mathrm{S}\right.$, 49 $20^{\prime} 47.92 "$ W) in October of 2014. The plant identification was performed by José Tadeu Weidlich Motta, at the Botanical Garden of Curitiba (MBM) Herbariums and voucher was deposited under the number MBM 320419. The research was authorized by the National Council for Scientific and Technological Development for access to Genetic Heritage under the number 02001.001165/2013-47.

\section{Extraction of the essential oil}

Hydrodistillation using water vapor drag was performed using a modified Clevenger apparatus [11] to extract the essential oil from the leaves dry of E. pyriformis. The extracted oils were stored in tightly closed dark bottles under refrigeration at $4^{\circ} \mathrm{C}$ until analyzed and tested.

\section{Gas chromatography-mass spectrometry analysis}

Gas chromatography mass spectrometry (GC-MS) (GC-MS-QP 2010 Plus, Shimadzu) was performed using a capillary column RTX - 5MS $(30 \mathrm{~m} \times 0.25 \mathrm{~mm} \times 0.25 \mu \mathrm{m})$. The samples were diluted at $1 \%(\mathrm{v} / \mathrm{v})$ in methylene chloride. Injector in splitless mode at $250^{\circ} \mathrm{C}$, ion source and interface at $300^{\circ} \mathrm{C}$. The mass window was analyzed from m/z 40 and m/z 350 using helium as the carrier gas at a flow rate of $1.02 \mathrm{~mL} / \mathrm{min}$, in $1: 90$ split mode, injection volume $=0.1 \mu \mathrm{L}$ (split ratio of 1:10). Ramp injection for analysis injector temperature 250 ${ }^{\circ} \mathrm{C}$, pressure of $20 \mathrm{psi}$ column, starting at $50^{\circ} \mathrm{C}$ for $5 \mathrm{~min}$ increasing to $200^{\circ} \mathrm{C}$ at a rate of $5^{\circ} \mathrm{C} / \mathrm{min}$.

\section{Identification and quantification of essential oil constituents}

The relative amount of individual components in the total oil is expressed as a percentage peak area relative to total peak area. The Kovats indices $(\mathrm{KI})$ were calculated by comparing the retention times of the eluting peaks with those of $\mathrm{C}_{5}-\mathrm{C}_{28}$ n-alkanes, injected under the same conditions as the samples. Identification of the oil components was performed by comparing their $\mathrm{KI}$ and mass spectra with those reported in the NIST library and in the literature [12].

\section{Antibacterial activity}

The antibacterial activity tests were performed using the following strains: Enterococcus faecalis ATCC 29212, Staphylococcus aureus ATCC 25923, MRSA ATCC 33591, Staphylococcus epidermidis ATCC 12228, Escherichia coli ATCC 25922, Klebsiella pneumoniae ATCC 700603, Pseudomonas aeruginosa ATCC 27853, Salmonella typhimurium ATCC 14028, and Enterobacter aerogenes ATCC 13048.

The MIC was determined using the broth microdilution technique [13]. Bacterial suspensions were prepared at a concentration of $1.0 \times 10^{8} \mathrm{CFU} \cdot \mathrm{mL}^{-1}$ with saline corresponding to 0.5 tube of the McFarland scale, and $5 \mu \mathrm{L}$ of the suspension was inoculated into each well at a final concentration of $10^{4} \mathrm{CFU} \cdot \mathrm{mL}^{-1}$. The negative control of inhibitory activity of the diluent was prepared by adding $100 \mu \mathrm{L}$ of $5 \%$ Polysorbate 80 in $100 \mu \mathrm{L}$ of Mueller-Hinton broth (MHB) and $5 \mu \mathrm{L}$ of bacterial inoculum. For controlling the sterility, $100 \mu \mathrm{L}$ of MHB and $100 \mu \mathrm{L}$ of the samples were used. Bacterial viability or positive controls were prepared with $100 \mu \mathrm{L}$ of MHB and $5 \mu \mathrm{L}$ of bacterial inoculum.

The microplates were incubated at $35^{\circ} \mathrm{C}$ for 16 to $20 \mathrm{~h}$. After this interval, $20 \mu \mathrm{L}$ of triphenyltetrazolium chloride aqueous solution (TTC; Merck, Darmstadt, Germany) were added to the microplates and then reincubated for $3 \mathrm{~h}$ at $35^{\circ} \mathrm{C}$. Development of red color was interpreted as the absence of antimicrobial activity.

The results were classified as good inhibitory activity (above $100 \mu \mathrm{g} \cdot \mathrm{mL}^{-1}$ ), moderate inhibitory activity (between 100 and $500 \mu \mathrm{g} \cdot \mathrm{mL}^{-1}$ ), weak inhibitory activity (between 500 and $1000 \mu \mathrm{g} \cdot \mathrm{mL}^{-1}$ ), and absence of inhibitory activity (above $1000 \mu \mathrm{g} \cdot \mathrm{mL}^{-1}$ ) [14].

\section{Antifungal activity}

The antifungal activity was evaluated using Candida albicans ATCC 14053, Candida krusei ATCC 6258, and Candida parapsilosis ATCC 22019. Serial dilutions of the sample were prepared in a concentration range of 7.81-1000 $\mu \mathrm{g} \cdot \mathrm{mL}^{-1}$ in RPMl 1640 liquid medium (Gibco/Invitrogen, New York, USA) [15] The different fungal suspensions were prepared in physiological saline at an initial concentration of $1.0 \times 10^{8} \mathrm{CFU} \cdot \mathrm{mL}^{-1}$. These were diluted in a liquid medium to a final concentration of 1.0 to $5.0 \times 10^{3} \mathrm{CFU} \cdot \mathrm{mL}^{-1}$ and then inoculated with 
$100 \mu \mathrm{L}$ into wells. The microplates were incubated for $48 \mathrm{~h}$ at $35^{\circ} \mathrm{C}$. Then, $20 \mu \mathrm{L}$ of $0.5 \%$ TTC was added and the plates were reincubated for $3 \mathrm{~h}$ at $35^{\circ} \mathrm{C}$. The results were analyzed according to the same method as that used for determination of the antibacterial activity.

\section{Brine shrimp lethality assay}

This toxicity assay, which uses the larvae of the brine shrimp $A$. salina Leach., was first described by Meyer et al. [16] The cysts were placed to hatch in a saline solution for $48 \mathrm{~h}$, producing a larger number of larvae. The essential oil diluted in $0.5 \%$ of Polysorbate 80 and saline solution was examined at concentrations of 10,100 , and $1000 \mu \mathrm{g} \cdot \mathrm{mL}^{-1}$, followed by a positive control prepared with saline solution and sodium dodecylsulfate (SDS), and negative control with saline solution and Polysorbate 80 . The assay was performed in triplicate. The tubes were incubated in the oven $\left(27-30^{\circ} \mathrm{C}\right)$ for $24 \mathrm{~h}$ and subsequently the nauplii were counted. The data were statistically analyzed using the Probitos method, which provided LC50 with $95 \%$ reliability. The degree of toxicity was classified as low toxicity, LC50 >500 $\mu \mathrm{g}^{\mathrm{mL}} \mathrm{L}^{-1}$; moderate toxicity, LC50 between $100 \mu \mathrm{g} \cdot \mathrm{mL}^{-1}$ and $500 \mu \mathrm{g} \cdot \mathrm{mL}^{-1}$; and high toxicity, LC50 < $100 \mu \mathrm{g} \cdot \mathrm{mL}^{-1}$ [17].

\section{RESULTS AND DISCUSSION}

\section{Chemical composition of the essential oil}

The yield of the oil essential from leaves of E. pyriformis Cambess. obtained by hydrodistillation was $0.14 \%$. Analysis of the essential oil indicated the presence of 36 constituents, which accounted for $78.80 \%$ of the total oil composition. The constituents identified, their retention indices, and their relative amounts are summarized in Table 1.

Table 1. Composition of the essential oils from leaves of E. pyriformis Cambess.

\begin{tabular}{|c|c|c|c|c|c|c|}
\hline No. $^{a}$ & $t_{\mathrm{R}}[\min .]^{\mathrm{b}}$ & Compound name & $\mathbf{R I}^{\mathrm{c}}$ & RIt $^{d}$ & $(\%)^{e}$ & Id. $^{f}$ \\
\hline 1 & 5.27 & Hexadienol & 908 & 916 & 0,71 & $R I, \mathrm{MS}$ \\
\hline 2 & 5.82 & Isocitronellene & 927 & 923 & 0.24 & $R I, \mathrm{MS}$ \\
\hline 3 & 6.37 & Heptenol & 947 & 954 & 1.07 & $R I, \mathrm{MS}$ \\
\hline 4 & 6.73 & Cumene & 960 & 924 & 0.37 & $R I, \mathrm{MS}$ \\
\hline 5 & 7.20 & $\beta$-Pinene & 976 & 974 & 0.16 & $R I, \mathrm{MS}$ \\
\hline 6 & 7.72 & Mesitylene & 995 & 994 & 0.60 & $R I, \mathrm{MS}$ \\
\hline 7 & 7.76 & n-Decane & 996 & 1000 & 0.91 & $R I, \mathrm{MS}$ \\
\hline 8 & 11.45 & n-Undecane & 1097 & 1100 & 0.28 & $R I, \mathrm{MS}$ \\
\hline 9 & 14.94 & Terpinen-4-ol & 1178 & 1174 & 0.34 & $R I, \mathrm{MS}$ \\
\hline 10 & 15.54 & $\alpha$-Terpineol & 1193 & 1186 & 0.35 & $R I, \mathrm{MS}$ \\
\hline 11 & 21.92 & $\delta$-Elemene & 1337 & 1335 & 0.39 & $R I, \mathrm{MS}$ \\
\hline 12 & 23.61 & $\alpha$-copaene & 1376 & 1374 & 3.83 & $R I, \mathrm{MS}$ \\
\hline 13 & 24.02 & $\beta$-Bourbonene & 1385 & 1387 & 0.35 & $R I, \mathrm{MS}$ \\
\hline 14 & 24.32 & $\beta$-Elemene & 1392 & 1389 & 1.97 & $R I, \mathrm{MS}$ \\
\hline 15 & 25.11 & a-Gurjunene & 1411 & 1409 & 1.29 & $R I, \mathrm{MS}$ \\
\hline 16 & 25.54 & $\beta$-caryophyllene & 1421 & 1417 & 17.82 & $R I, \mathrm{MS}$ \\
\hline 17 & 25.93 & $\beta$-Copaene & 1430 & 1430 & 0.68 & $R l, \mathrm{MS}$ \\
\hline 18 & 26.36 & Aromandrene & 1440 & 1439 & 2.21 & $R I, \mathrm{MS}$ \\
\hline 19 & 26.54 & a-Guaiene & 1445 & 1437 & 0.37 & $R I, \mathrm{MS}$ \\
\hline 20 & 26.99 & a-Humulene & 1455 & 1452 & 2.69 & $R I, \mathrm{MS}$ \\
\hline 21 & 27.30 & 9-epi-(E)-Caryophyllene & 1463 & 1464 & 2.17 & $R I, \mathrm{MS}$ \\
\hline 22 & 27.94 & $\gamma$-Muurolene & 1478 & 1478 & 0.70 & $R I, \mathrm{MS}$ \\
\hline
\end{tabular}


Cont. Table 1

\begin{tabular}{|c|c|c|c|c|c|c|}
\hline 23 & 28.14 & Germacrene-D & 1483 & 1484 & 2.79 & $R I, \mathrm{MS}$ \\
\hline 24 & 28.37 & $\beta$-Selinene & 1488 & 1489 & 0.25 & $R I, \mathrm{MS}$ \\
\hline 25 & 28.82 & Bicyclogermacrene & 1499 & 1500 & 12.84 & $R I, \mathrm{MS}$ \\
\hline 26 & 28.95 & a-Muurolene & 1502 & 1500 & 1.06 & $R I, \mathrm{MS}$ \\
\hline 27 & 29.52 & $\gamma$-Cadinene & 1516 & 1513 & 0.54 & $R I, \mathrm{MS}$ \\
\hline 28 & 29.97 & $\delta$-Cadinene & 1525 & 1522 & 4.33 & $R I, \mathrm{MS}$ \\
\hline 29 & 31.43 & Maaliol & 1564 & 1567 & 0.35 & $R I, \mathrm{MS}$ \\
\hline 30 & 32.18 & Esphatulenol & 1582 & 1577 & 3.24 & $R l, \mathrm{MS}$ \\
\hline 31 & 32.43 & Globulol & 1588 & 1590 & 5.96 & $R I, \mathrm{MS}$ \\
\hline 32 & 32.75 & Viridiflorol & 1596 & 1592 & 3.52 & $R I, \mathrm{MS}$ \\
\hline 33 & 33.15 & Rosifoliol & 1606 & 1600 & 1.18 & $R I, \mathrm{MS}$ \\
\hline 34 & 33.96 & 5-epi-7-epi- $\alpha$-Eudesmol & 1627 & 1607 & 0.91 & $R I, \mathrm{MS}$ \\
\hline 35 & 34.70 & Tau-muurolol & 1647 & 1640 & 1.03 & $R I, \mathrm{MS}$ \\
\hline \multirow[t]{10}{*}{36} & 34.93 & a-Cadinol & 1660 & 1652 & 1.30 & $R I, \mathrm{MS}$ \\
\hline & & Total identification [\%] & & & 78.80 & \\
\hline & & Aromatic hydrocarbons [\%] & & & 0.97 & \\
\hline & & Alcohols [\%] & & & 0.71 & \\
\hline & & Aldehydes [\%] & & & 1.07 & \\
\hline & & Hydrocarbon alkane [\%] & & & 0.28 & \\
\hline & & Monoterpene hydrocarbons [\%] & & & 0.40 & \\
\hline & & Monoterpene oxygenated [\%] & & & 0.69 & \\
\hline & & Sesquiterpene hydrocarbons [\%] & & & 57.19 & \\
\hline & & Oxigenated sesquiterpenes [\%] & & & 17.49 & \\
\hline
\end{tabular}

a Order of elution is given on apolar column (Rtx-5MS). Bold types refer to main compounds. ${ }^{b}$ Time retention on the apolar Rtx-5MS column. ${ }^{c}$ Retention indices on the polar Rtx-5MS column. ${ }^{d}$ Kovats retention index relative to $\mathrm{n}-$

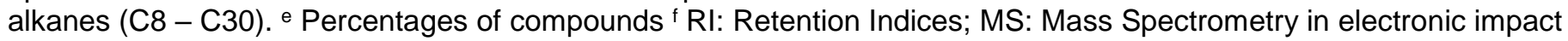
mode.

The essential oil of leaves of E. pyriformis is mainly composed of sesquiterpene hydrocarbons (57.19\%) and oxygenated sesquiterpenes $(17.49 \%)$, with smaller amounts of aldehydes $(1.07 \%)$, aromatic hydrocarbon $(0.97 \%)$, alcohols $(0.71 \%)$, monoterpene oxygenated $(0.69 \%)$, monoterpene hydrocarbons $(0.40 \%)$ and hydrocarbon alkane $(0.28 \%)$. The major constituents were found to $\beta$-Caryophyllene $(17,82 \%)$, Bicyclogermacrene (12,84\%), Globulol (5,96\%) and $\delta$-Cadinene (4,33\%). Other representative components of the oil were identified as $\alpha$-Copaene (3.83\%), Esphatulenol (3.24\%), Germacrene-D (2.79\%), $\alpha$-Humulene (2.69\%), Aromandrene (2.21\%) and 9-epi-(E)-Caryophyllene (2.17\%) (Figure 1). 


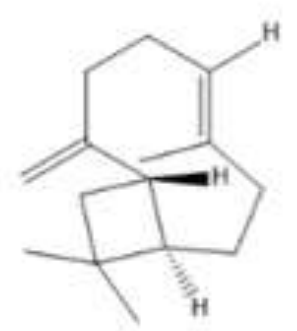

1

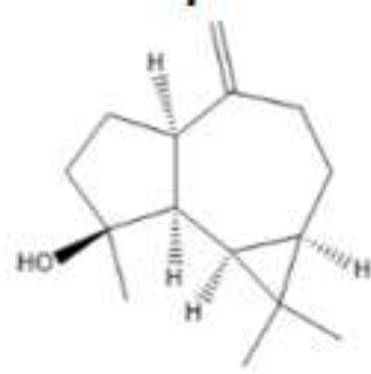

6

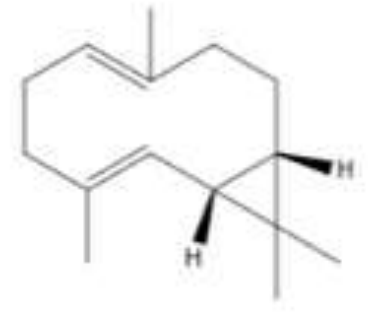

2

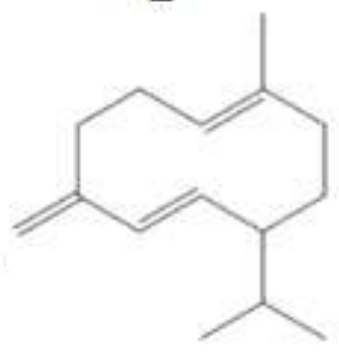

7

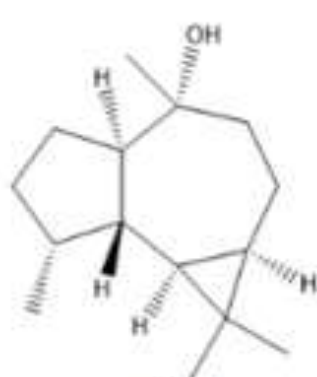

3

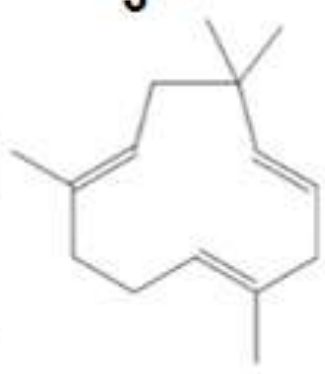

8

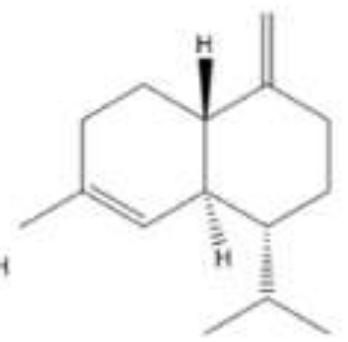

4

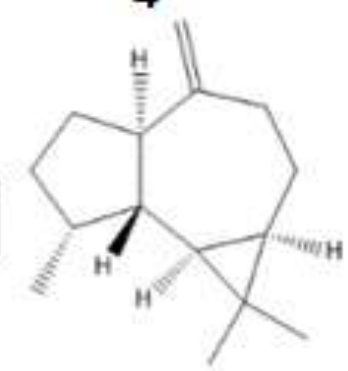

9

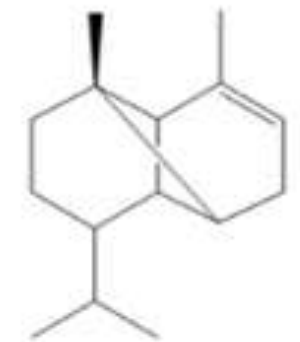

5

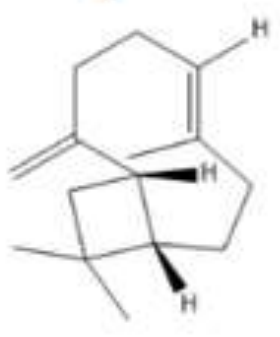

10

Figure 1. Chemical structures of the major compounds of essential oils from leaves of Eugenia pyriformis Cambess. $\beta$ Caryophyllene (1), Bicyclogermacrene (2), Globulol (3), $\delta$-Cadinene (4), $\alpha$-Copaene (5), Esphatulenol (6), Germacrene$\mathrm{D}(\mathbf{7})$, a-Humulene (8), Aromandrene (9) and 9-epi-(E)-Caryophyllene (10).

The essential oil obtained from the plants of Eugenia species have high levels of cyclic sesquiterpenes and low levels of monoterpenes. A few species produce aliphatic and aromatic compounds. The sesquiterpene $\beta$-caryophyllene and the monoterpene $\alpha$-pinene are the most abundant compounds in the essential oil plants of the Eugenia species [9].

Previous studies have shown that $\beta$-caryophyllene and bicyclogermacrene are present in the essential oil obtained from species other than $E$. pyriformis. $\beta$-Caryophyllene is a major component of essential oil of E. Klotzschiana [18], E. moraviana [19], E. argentea [5] and E. involucrata [20]; it is abundantly present in the essential oil of E. stipitata [21] and E. umbeliflora [19].

$\beta$-Caryophyllene and bicyclogermacrene are present in moderate amounts in the essential oil obtained from E. burkartiana [19], E. ramboi [19], E. repanda [22], E. cuprea, E. pitanga [23], E. beaurepaireana [23], E. hyemalis [23], E. mattosii [24] and E. klotzschiana [18,25].

Sesquiterpene compounds are widely found in the essential oils of medicinal plants and fruits and are used for the treatment of various conditions [26]. $\beta$-Caryophyllene has several properties such as anti-edema, phagorepullic, anti-inflammatory, antitumor, insecticidal, spasmolytic, bactericidal properties [18], and bicyclogermacrene has antifungal activity [27].

\section{Antimicrobial activities} Table 2.

The MIC of the essential oil of E. pyriformis obtained using the antimicrobial activity test are shown in 
Table 2. Antimicrobial activity of leaves essential oil of E. pyriformis Cambess.

\begin{tabular}{ll}
\hline Microorganisms & MIC $\left(\mu \mathrm{g} \cdot \mathrm{mL}^{-1}\right)$ \\
\hline Gram-positive & 250 \\
S. aureus ATCC 25923 & 125 \\
MRSA ATCC 33591 & 1000 \\
S. epidermidis ATCC 12228 & $>1000$ \\
E. faecalis ATCC 29212 & \\
Gram-negative & $>1000$ \\
E. coli ATCC 25922 & $>1000$ \\
K. pneumoniae ATCC 700603 & $>1000$ \\
P. aeruginosa ATCC27853 & $>1000$ \\
E. aerogenes ATCC 13048 & 1000 \\
S. typhimurium ATCC 14028 & \\
Leveduriform fungi & $>1000$ \\
C. albicans ATCC 14053 & $>1000$ \\
C. krusei ATCC 6258 & $>1000$ \\
C. parapsilosis ATCC 22019 &
\end{tabular}

MIC, minimum inhibitory concentration (given as $\mu \mathrm{g} \cdot \mathrm{mL}^{-1}$ ).

To validate the technique and methodological control, vancomycin and fluconazole were used, and the confidence interval was stipulated using the Clinical and Laboratory Standards Institute (CLSI) method [13].

The essential oil of $E$. pyriformis showed moderate antibacterial potential against the gram-positive bacteria S. aureus and methicillin-resistant S. aureus (MRSA) with MIC values of 250 and $125 \mu \mathrm{g} \cdot \mathrm{mL}^{-1}$, respectively. A previous study using the essential oil obtained from $E$. umbelliflora and $E$. brasiliensis showed an MIC of 119 and $156 \mu \mathrm{g} \cdot \mathrm{mL}^{-1}$, respectively, against $S$. aureus [24]. The essential oil from E. axillaris had an MIC of $625 \mu \mathrm{g} \cdot \mathrm{mL}^{-1}$ for $S$. aureus. In addition, we evaluated the antimicrobial activities of 4-terpineol, $\alpha$ terpineol, $\beta$-caryophyllene, $\alpha$-humulene, and germacrene-D; the MIC of these compounds was 39-1250 $\mu \mathrm{g} \cdot \mathrm{mL}^{-1}[7]$.

$S$. aureus is an important etiological agent associated with acquired infections, both in the community and in hospitals. S. aureus is the most frequently isolated bacterial pathogen associated with several serious clinical infections, including endovascular and soft tissue infections, pneumonia, and sepsis, and has a high prevalence and a high degree of pathogenicity [28,29]. MRSA is a well-known nosocomial pathogen, often associated with health care and acquired in the community. MRSA is resistant to penicillin and other available $\beta$-lactam antibiotics, limiting potential treatment options with standard antibiotic therapy and increasing the risk of more unfavorable clinical outcomes for patients [29].

S. epidermidis and Salmonella typhimurium showed MICs of $1000 \mu \mathrm{g} \cdot \mathrm{mL}^{-1}$, which indicated a weak inhibitory potential according to the established scale. The MICs of other microorganisms were above 1000 $\mu \mathrm{g} \cdot \mathrm{mL}^{-1}$. S. epidermidis is a human pathogen that colonizes body surfaces, is prevalent in moist areas such as the armpits, inguinal and perineal area, nostrils, and conjunctivae [30]. S. typhimurium is a food-borne pathogen that causes salmonellosis, a gastrointestinal disease of public health importance, which affects humans and animals [31].

Resistance to antibiotics available in the market is increasing at alarming levels, whereas the development of new antimicrobial agents is taking place at a slow rate. The development of resistance and the emergence of new bacterial pathogens warrants the development of new drugs, and thus new discovery, surveillance, and control programs must be implemented on a priority basis. Medicinal plants and fungi have been widely used in the past to combat human and animal pathogens and may be the key to the production of new antibiotics [32]. 


\section{Brine shrimp lethality bioassay}

The brine shrimp bioassay is used to evaluate the acute toxicity and is a preliminary assay in the study of compounds with potential biological activities [33]. This assay is an economical method for investigating the activities of compounds obtained from plants, particularly in countries where plant-based medicines are commonly used [34]. The results obtained from this bioassay correlate with those of cytotoxicity to $9 \mathrm{~Kb}$ and 9PS cells (leukemia); thus, the brine shrimp lethality bioassay may be used for the preliminary determination of antitumor activity [16,35].

The essential oil from E. pyriformis was toxic with a lethal concentration required to kill $50 \%$ of the population (LC50) of $125.64\left(\mu \mathrm{g} \cdot \mathrm{mL}^{-1}\right)$. Previous studies have reported the toxic effects of essential oils from species of plants to Artemia salina. Studies using the essential oil from E. uniflora showed an LC50 of 253.43 $\mu \mathrm{g} \cdot \mathrm{mL}^{-1}[36]$. E. uniflora is used in folk medicine as a diuretic, antirheumatic, antipyretic, and anti-inflammatory agents and for the diseases of the stomach [37].

The in vitro cytotoxic effects of the essential oil obtained from the leaves of $E$. zuchowskiae was examined using the MCF-7 (mammary adenocarcinoma), MDA-MB-468 (mammary adenocarcinoma), and UACC-257 (malignant melanoma) human tumor cell lines; the leaf oil was cytotoxic with $100 \%$ kill at a concentration of $100 \mu \mathrm{g} \cdot \mathrm{mL}^{-1}$ on the cell lines tested. The cytotoxic effects of the major components $\alpha$-pinene, $\alpha$-copaene, $\beta$-caryophyllene, and $\alpha$-humulene of the essential oil on MCF-7 cells were similar to those of the anticancer agent doxorubicin [38].

\section{CONCLUSION}

Our results indicate that the essential oil of E. pyriformis Cambess. predominantly consists of hydrocarbon sesquiterpenes, and $\beta$-caryophyllene, bicyclogermacrene, globulol, and $\delta$-cadinene are present in high levels. The essential oil obtained from E. pyriformis shows marked toxicity to $A$. salina and antibacterial activity against several gram-positive bacteria. The essential oil was effective against MRSA. Further in vitro cytotoxicity studies should be performed to identify new drugs with an anticancer potential. The promising results observed using this oil provide insights for developing an alternative to commercially available drugs for treating infections caused by drug-resistant bacteria. Further studies using this species should be performed to identify new molecules for the treatment of diseases associated with microbial pathogens and malignancies.

Acknowledgements: The authors are grateful to the Postgraduate Program in Pharmaceutical Sciences, Department of Chemistry of the Federal University of Paraná, Brazil for the assistance in GC-MS analysis.

Conflicts of Interest: All authors have no conflict of interest to declare.

\section{REFERENCES}

1. Arruda RCO, Victório CP. Leaf Secretory Structure and Volatile Compounds of Eugenia copacabanensis Kiaersk. (Myrtaceae). J Essent Oil Res. 2011;23(5):1-6.

2. Ferreira FPS, Morais SR, Bara MTF, Conceição EC, Paula JR, Carvalho TC, Vaz BG, Costa HB, Romão W, Rezende $\mathrm{MH}$. Eugenia calycina Cambess extracts and their fractions: Their antimicrobial activity and the identification of major polar compounds using electrospray ionization FT-ICR mass spectrometry. J Pharm Biomed Anal. 2014;99:89-96.

3. Lago JHG, Souza ED, Mariane B, Pascon R, Vallim MA, Martins RCC, Baroli AA, Carvalho BA, Soares MG, Dos Santos RT, Sartorelli P. Chemical and biological evaluation of essential oils from two species of myrtaceae Eugenia uniflora L. and Plinia trunciflora (O. Berg) kausel. Molecules. 2011;16(12):9827-37.

4. Souza AM, Armstrong L, Merino FJZ, Cogo LL, Monteiro CLB, Duarte MR, Miguel OG, Miguel MD. In vitro effects of Eugenia pyriformis Cambess., Myrtaceae: Antimicrobial activity and synergistic interactions with Vancomycin and Fluconazole. African J Pharm Pharmacol. 2014;8(35):862-67.

5. Raj G, George V, Sethuraman MG. Chemical analysis of essential oil from the leaves of Eugenia argentea Bedd. J Essent Oil Res. 2011;23(3):55-7.

6. Cecílio AB, Faria DB, Oliveira PDC, Caldas S, Oliveira DA, Sobral MEG, Duarte MGR, Moreira CPDS, Silva CG, Almeida VL. Screening of Brazilian medicinal plants for antiviral activity against rotavirus. J Ethnopharmacol. 2012; 141(3):975-81.

7. Schmidt JM, Noletto JA, Vogler B, Setzer WN. Abaco bush medicine: chemical composition of the essential oils of four aromatic medicinal plants from Abaco Island, Bahamas. J Herbs Spices Med Plants. 2006;12(3):43-65.

8. Magina MDA, Dalmarco EM, Dalmarco JB, Colla G, Pizzolatti MG, Brighente IMC. Bioactive triterpenes and phenolics of leaves of Eugenia brasiliensis. Quim Nova. 2012;35(6):1184-8. 
9. Pascoal ACRF, Salvador MJ. Essential Oils from Neotropical Myrtaceae: Chemical Diversity and Biological Properties. Chem Biodivers. 2011;8(1):73-94.

10. Armstrong L, Duarte MR, Miguel OG. Morpho-anatomy of the leaf and stem of Eugenia pyriformis. Brazilian $\mathrm{J}$ Pharmacogn. 2012;22(3):475-81.

11. Brazilian Pharmacopoeia, National Health Surveillance Agency, 2010, 5 ed, 1-523.

12. Adams RP. Identification of essential oil components by gas chromatography/mass spectrometry. Allured Publishing Corporation. 2007;4:804.

13. Clinical and Laboratory Standards Institute, 'Methods for Dilution Antimicrobial Susceptibility Tests for Bacteria That Grow Aerobically', M07A9, Wayne, PA, USA: CLSI, 2012.

14. Ayres MCC, Brandão MS, Vieira-Júnior GM, Menor JCAS, Silva HB, Soares MJS, Chaves MH. Antibacterial activity of useful plants and chemical constituents of Copernicia prunifera root. Brazilian J Pharmacogn. 2008; 18(1):90-7.

15. Clinical and Laboratory Standards Institute. Reference method for broth dilution antifungal susceptibility testing of filamentous fungi: approved standard document M38-A2. Wayne, P.A.: CLSI, 2008.

16. Meyer BN, Ferrigni NR, Putnam JE, Jacobsen LB, E. ND, McLaughlin JL, Nichols DE. Brine shrimp a convenient general bioassay for active plants constituents. J Med Plant Res. 1982;45(1):31-4.

17. Amarante $\mathrm{CB}$, Müller AH, Póvoa MM, Dolabela MF. Phytochemical biomonitoring study of toxicity tests against Artemia salina and antiplasmodic activity of the Aninga stem (Montrichardia linifera). Acta amaz. 2011;41(3):4314.

18. Carneiro NS, Alves JM, Alves CC, Esperandim VR., Miranda MLD. Essential Oil of the Flowers of Eugenia klotzschiana (Myrtaceae): Chemical Composition and Tripanocidal and Cytotoxic In Vitro Activities. Rev Virtual Quimica. 2017;9(3):1381-92.

19. Apel MA, Limberger RP, Sobral M, Henriques AT, Ntalani H, Vérin P, Menut C, Bessière JM. Chemical composition of the essential oils from Southern Brazilian Eugenia species. Part III. J Essent Oil Res. 2002;14(4):259-62.

20. Raseira M, Marin R, Apel MA, Limberger RP, Raseira MCB. Volatile Components and Antioxidant Activity from some Myrtaceous Fruits cultivated in Southern Brazil. Latim. Am. J. Pharm. 2008; 27(2):172-7.

21. Medeiros JR, Medeiros N, Medeiros H, Davin LB, Lewis NG. Composition of the bioactive essential oils from the leaves of Eugenia stipitata McVaugh ssp Sororia from the Azores. J Essent Oil Res. 2003;15(4):293-5.

22. Apel MA, Limberger RP, Sobral M, Henriques AT, Ntalani H, Vérin P, Menut C, Bessière JM. Chemical composition of the essential oils from Southern Brazilian Eugenia species. Part III. J Essent Oil Res. 2002;14(4):259-62.

23. Apel MA, Sobral M, Schapoval EES, Henriques AT, Menut C, Bessiere JM. Essential Oils from Eugenia SpeciesPart VII: Sections Phyllocalyx and Stenocalyx. J Essent Oil Res. 2004; 16(2):135-8.

24. Magina MDA, Pietrovski EF, Gomig F, Falkenberg DDB, Cabrini DA, Otuki MF, Pizzollati MG, Brighente IMC. Topical antiinflammatory activity and chemical composition of the epicuticular wax from the leaves of Eugenia beaurepaireana (Myrtaceae). Brazilian J Pharm Sci. 2009;45(1):171-6.

25. Cole RA, Bansal A, Moriarity DM, Haber WA, Setzer WN. Chemical composition and cytotoxic activity of the leaf essential oil of Eugenia zuchowskiae from Monteverde, Costa Rica. J Nat Med. 2007;61(4):414-7.

26. Petronilho S, Maraschin M, Coimbra MA, Rocha SM. In vitro and in vivo studies of natural products: A challenge for their valuation. The case study of chamomile (Matricaria recutita L .). Ind Crop Prod. 2012; 40:1-12.

27. Silva L, Oniki GH, Agripino DG, Moreno PRH, Young MCM, Mayworm MAS, Ladeira AM. Bicyclogermacrene, resveratrol and antifungal activity in leaf extracts of Cissus verticillata (L.) Nicolson \& Jarvis (Vitaceae). Braz $\mathrm{J}$ Pharmacogn. 2007; 17(3):361-7.

28. Breves A, Miranda CAC, Flores C, Filippis I, Clementino MM. Methicillin- and vancomycin-resistant Staphylococcus aureus in health care workers and medical devices. Brazilian J Pathol Lab Med. 2015;51(3):143-52.

29. Narayanaswamy VP, Giatpaiboon SA, Uhrig J, Orwin P, Wiesmann W, Baker SM, Townsend SM. In Vitro activity of novel glycopolymer against clinical isolates of multidrug-resistant Staphylococcus aureus. Plos One. 2018;13(1):1-16.

30. Becker K, Heilmann C, Peters G. Coagulase-Negative Staphylococci. Clinical microbiology reviews. 2014;27(4):870-926.

31. Whiley H, Gardner MG, Ross K. A Review of Salmonella and Squamates (Lizards, Snakes and Amphisbians ): Implications for Public Health, Pathogens, 2017;6(3):1-15.

32. Roca I, Akova M, Baquero F, Carlet J, Cavaleri M, Coenen S, Cohen J, Findlay D, Gyssens I, Heure OE. The global threat of antimicrobial resistance: science for intervention. New Microbes New Infect. 2015;16(6):22-9.

33. Kalegari M, Miguel MD, Dias JFG, Lordello ALL, Lima CP, Miyazaki CMS, Zanin SMW, Verdam MCS, Miguel OG. Phytochemical constituents and preliminary toxicity evaluation of leaves from Rourea induta Planch. (Connaraceae). Brazilian J. Pharm. Sci. 2011; 47(3):635-42.

34. Soares BV, Morais SM, Fontenelle ROS, Queiroz VA, Vila-Nova NS, Pereira CMC, Brito ESEHS, Neto MAS, 
Cavalcante CSP, Castelo-Branco DSCM, Rocha MFG. Antifungal activity, toxicity and chemical composition of the essential oil of Coriandrum sativum L. fruits. Molecules 2012;17(7):8439 -48.

35. McLaughlin JL, Rogers LL, Anderson JE. The Use of Biological Assays to Evaluate Botanicals. Drug Inf. J. 1998; 32:513-24.

36. Leite AM, Lima EDO, Souza EL, Diniz MFFM, Leite SP, Xavier AL, Medeiros IA. Preliminary study of the molluscicidal and larvicidal properties of some essential oils and phytochemicals from medicinal plants. Brazilian J. Pharmacogn. 2009;19(4): 842-6.

37. Victoria FN, Lenardo EJ, Savegnago L, Perin G, Jacob RG, Alves D, Silva WP, Motta AS, Nascente PS. Essential oil of the leaves of Eugenia uniflora L.: Antioxidant and antimicrobial properties, Food Chem. Toxicol. 2012; 50(8): 2668-74.

38. Cole RA, Bansal A, Moriarity DM, Haber WA, Setzer WN. Chemical composition and cytotoxic activity of the leaf essential oil of Eugenia zuchowskiae from Monteverde, Costa Rica, J. Nat. Med. 2007; 61:414-17.

(C) 2021 by the authors. Submitted for possible open access publication under the terms and conditions of the Creative Commons Attribution (CC BY NC) license (https://creativecommons.org/licenses/by-nc/4.0/). 